\title{
Contributions to Genus Astragalus L. (Fabaceae) in Turkey
}

\section{Zeki AYTAÇ ${ }^{1}$ Ergin HAMZAOĞLU², Murat EKICI ${ }^{1}$, Seher KARAMAN ERKUL ${ }^{*}, 3$, Tuğba ERTUĞRUL ${ }^{1}$}

\author{
${ }^{1}$ Gazi University, Faculty of Science, Department of Biology, Ankara, Turkey \\ ${ }^{2}$ Gazi University, Gazi Faculty of Education, Department of Mathematics and Science Education, Ankara, Turkey \\ ${ }^{3}$ Aksaray University, Faculty of Science and Letters, Department of Biology, Aksaray, Turkey \\ ORCID ID: Zeki AYTAÇ: https:// orcid.org/0000-0003-3244-3183; Ergin HAMZAOĞLU: https:/ /orcid.org/0000-0001-6053-6796; Murat EKICI: \\ https:/ / orcid.org/0000-0002-3402-177X ; Seher KARAMAN ERKUL: https:/ / orcid.org/0000-0003-1239-8266; Tuğba ERTUĞRUL: \\ https://orcid.org/0000-0002-3621-6845
}

\begin{tabular}{l} 
Received: $23.09 .2020 \quad$ Accepted: $28.10 .2020 \quad$ Published online: $29.10 .2020 \quad$ Issue published: 31.12 .2020 \\
\hline Abstract: In this study, new arrangements are given for three Astragalus species that are endemic in Turkey. Astragalus physodes \\
subsp. acikirensis (sect. Cystium) was raised to the species level; Astragalus darendensis was reduced to synonym of Astragalus \\
scabrifolius (sect. Incani) and Astragalus tuna-ekimii was reduced to synonym of Astragalus chamaephaca (sect. Macrosemium). \\
Comments are provided on the relevant taxa about their taxonomic positions by examining the recollected samples and the \\
type samples.
\end{tabular}

Keywords: Cystium, Incani, Macrosemium, new arrangement.

\section{Türkiye'deki Astragalus L. (Fabaceae) Cinsine Katkılar}

Öz: Bu çalışmada Türkiye' de dağılış gösteren ve endemik olan üç Astragalus türü için yapılan yeni düzenlemeler sunulmuştur. Astragalus physodes subsp. acikirensis tür seviyesine çıkartılmış, Astragalus darendensis türü Astragalus scabrifolius' un ve Astragalus tuna-ekimii türü Astragalus chamaephaca'nın sinonimi olarak kabul edilmiştir. İlgili taksonlar yeniden toplanan örnekler ve tip örneklerinin incelenmesiyle taksonomik konumları hakkında yorumlar yapılmıştır.

Anahtar kelimeler: Cystium, Incani, Macrosemium, yeni düzenleme.

\section{Introduction}

The genus Astragalus L. is the largest genus of vascular plants with approximately 2900 species, which has two main centers of distribution in the world, Eurasia (Old World) and America (New World). Most of the species are located in the Old World (ca. 2400 species.) whereas ca. 500 species are restricted to the New World (Chaudhary, Rana, \& Anand, 2008, Zarre \& Azani, 2013).

Astragalus is the largest genus in the world in terms of the number of taxa (Podlech \& Zarre, 2013). It is also the most confusing group in terms of morphological structures. The identification of this genus uses many characteristics such as annual or perennial, spiny or not, herbs or shrub; stipule structures, adnate or notto the petiole, membranous or leathery; caulescent, acaulous, scapose or not; pairs of leaflets numbers; leaflet shapes and pubescence (simple, furcate, subbifurcate, black or white hairs); with or without bracts and bracteoles, structure of bracts and bracteoles; with pedicellate flowers or not; calyx inflated or not; legumes shape (ovate, oblong, linear), hairy or glabrous, unilocular or bilocular.

One of the important factors in species identification within the genus is the correct identification of the sections of the genus using the characters given above. One of significant mistakes is that it can be defined as a new species if the section to which the specimen belongs is defined inaccurately.

Since most of the section members are distributed over wide areas, they may morphologically show ecological differences in their structures. If there are not enough and different samples collected from them, taxonomists may make a mistake and describe these ecological variances as different taxa.

In the light of all this information, it was inevitable to make some status and combination changes regarding Astragalus in Turkey. Some of these findings are given below.

\section{Material and Methods}

The study materials consist of the information obtained as a result of examining type samples collected from field or examined in herbaria. ANK, GAZI, HUB, MSB, G, E, LE, and K herbaria were visited, and the type specimen's images on the digital herbaria (P, BR, BASBG) were examined (Thiers, 2020). Original materials were examined, especially holotypes and isotypes. The status of taxa has been changed in the light of the acquired information.

\section{Specimen examined:}

A. acikirensis: Turkey, Ankara: Polatlı, $18 \mathrm{~km}$ west of Polatlı, Acıkır district, 840- 850 m, steppe, 25.5.1990, Z. Aytaç 3031 \& H. Duman (Holotype GAZI!; Isotypes GAZI!, and ANK!); Kırıkkale: Delice $4 \mathrm{~km} \mathrm{~S}$ of Delice, 650 m, A.A. Dönmez 1822 (HUB!), Yozgat, Sekili, Sekili salt mine, $800 \mathrm{~m}, 7.05 .2020$, in gypsum steppe, Hamzaoğlu 7665 (GAZI!).

Astragalus chamaephaca: Turkey, Afyonkarahisar: Bayat, around Meliktepe, ca. 1300 m, 27.04.1975, Vural 
115 (GAZI!), Bayat, east of İnazarcik, ca. $1250 \mathrm{~m}$, 26.04.1975, Vural 115a (GAZI!); Amasia: prope Khaonsa, in declivibus regionis calidae nec non montanae,03.05.1889, Bornmüller 99 (Lectotype PH00005234!) (URL 1); Bitlis: Tatvan, Mount Nemrut, below Şahmiran village, 1900 m, 28.05.1972, Peşmen 2915 (Holotype, GAZI!) (Syn. A. tuna-ekimii); Samsun: 350-500 m, 5.05.1988, Duman 1989 (GAZI); Van: Tatvan-Van, 5 km, ca. 1800 m, 24.06.1983, Ekim 7616 (Paratype, GAZI!) (Syn. A. tuna-ekimii).

Astragalus scabrifolius: Turkey, Malatya: DarendeHekimhan, 33 km E of Darende, 1220 m, 04.06.1987, M. Nydegger 42631 (Holotype MSB004034! (URL 3), Isotype BASBG00000031! (URL 4).

\section{Results and Discussion}

3.1. Astragalus acikirensis (Ekim) Aytaç \& Hamzaoğlu (sect. Cystium Bunge). com. et stat. nova. Fig. 1.

Syn.: Astragalus physodes L. subsp. acikirensis Ekim, Thaiszia 1: 23 (1992).

One herbaceous Astragalus specimen was collected around Polatl district of Ankara (Turkey) in 1991. With inflated fruit and white flowers, it was identified as a new subspecies: A. physodes subsp. acikirensis (Ekim, Aytaç, \& Duman, 1991). When the taxon was published, it was defined as a subspecies of $A$. physodes, which grows in Northern Europe, Crimea, and Kazakhstan because of its bifurcate fruit and white flower.

In the original article, Astragalus physodes subsp. acikirensis was evaluated in the section Proselius Bunge (Ekim et al., 1991). However, it was transferred to section Cystium by Podlech (Podlech \& Zarre, 2013). The section Cystium was a new taxon for Flora of Turkey (Podlech \& Zarre, 2013). In 2007, Dural, Tugay, Ertuğrul, Uysal and Demirelma described a new species, A. turkmenensis

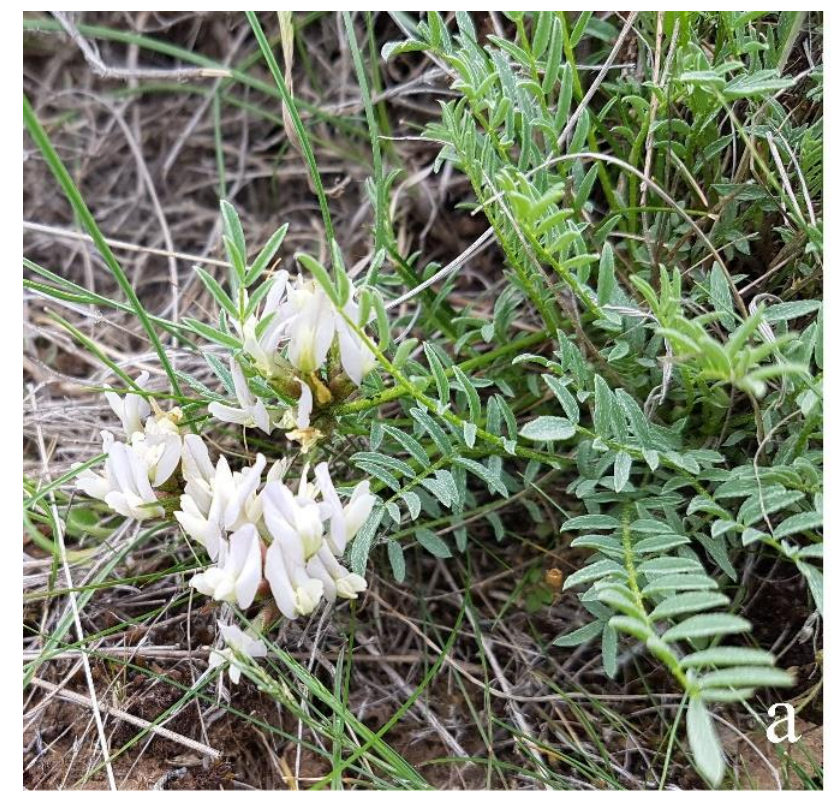

Dural, Tugay and Ertuğrul, in this section (Dural et al., 2007). According to Podlech and Zarre (2013), the corolla color of this section members are yellow or violet, legumes mostly glabrous or with appressed or spreading hairy.

The white corolla color and bifurcate legume structure were added to the sectional features (Table 1). Therefore, its description was expanded and rewritten.

Table 1. Comparison of the Astragalus physodes and A. acikirensis

\begin{tabular}{lll}
\hline Characteristics & A.physodes & A. acikirensis \\
\hline Leaflets & hairy on both surfaces & glabrous above \\
Flowers color & purple & pale lilac to white \\
Standards & $15-20 \mathrm{~mm}$ & $15-29 \mathrm{~mm}$ \\
Fruit & glabrous & appressed bifurcate pilose \\
Distribution & Euro-Siberian & Irano-Turanian (Turkey) \\
\hline
\end{tabular}

Description of the section based on Turkish members:

Section Cystium: Herbaceus, subacaulescent, covered bifurcate hairs; stipules adnate to the petiole. Racemes globose to ovoid and with short to long pedunculate. Bracteoles absent or rarely present. Calyx tubular, mostly black or predominantly black hairy. Petals yellow, violet to white. Legumes mostly glabrous, with appressed to spreading bifurcate hairy.

After re-examining type specimens and other specimens, it was revealed that the color of flowers in $A$. physodes subsp. acikirensis is pale lilac and white (not violet), the fruits bifurcate (not glabrous) and sometimes longer standard (15-29 mm, not 15-20 mm), leaflets sparsely hairy to glabrous as above.

As a result, the subspecies were elevated to species level. Comparative data of taxa are presented in Table 1.

This section is represented with Astragalus acikirensis and A. turkmenensis in Turkey. These two taxa are endemic for Turkey.

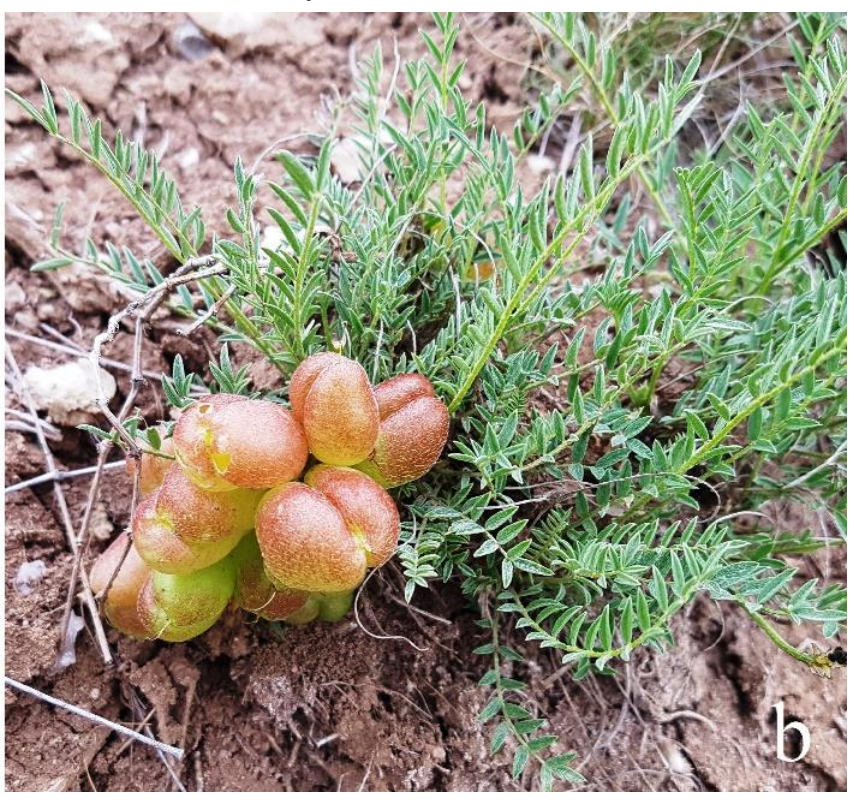

Figure 1. Habit of Astragalus acikirensis a. Flower, b. Fruit (Photographed by E. Hamzaoğlu).

3.2. Astragalus chamaephaca Freyn, Oesterr. Bot. Z. 40 (11): 402 (1890) (sect. Macrosemium Bunge). Fig. 2.

Syn.: Astragalus tuna-ekimii Adıgüzel, Ann. Bot. Fenn. 36(4): 231 (1999), syn. nova.
According to Flora of Turkey and the East Aegean Islands, the section Macrosemium is represented by Astragalus chamaephaca and $A$. paradoxus Bunge (Chamberlain \& Matthews 1970). A. chamaephaca is endemic but it is very common in Turkey and $A$. 
paradoxus is common to Iran, Turkey, Azerbaijan, and Armenia (Chamberlain \& Matthews, 1970; Podlech \& Zarre, 2013). A sample collected from Bitlis-Tatvan area in 1972 (Peşmen 2915, type in GAZI!) was identified as a new species in the same section as A. tuna-ekimii (Adigüzel, 1999). Therefore, its ecological variations are also quite many. After examining the type specimens of A. chamaephaca and A. tuna-ekimii species and numerous samples collected from different locations, it is

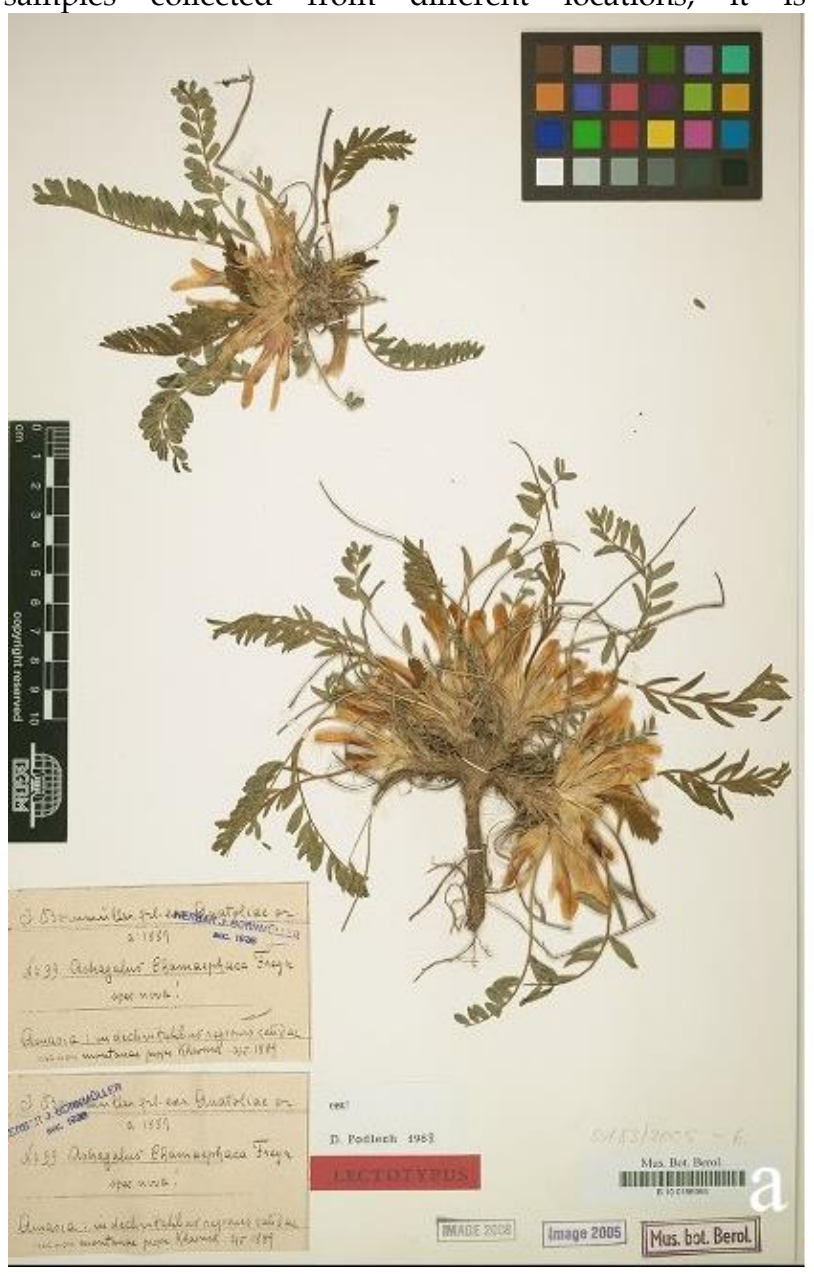

understood that the samples of these two species are the same. Therefore, A. tuna-ekimii is reduced to the synonym of $A$. chamaephaca, based on nomenclatural rules (Turland et al., 2018). According to Podlech and Zarre (2013), A. chamaephaca can turn black when its flowers dry. Such a blackening has not been observed in either the type sample or the other analyzed samples. Comparative data of taxa are presented in Table 2 .

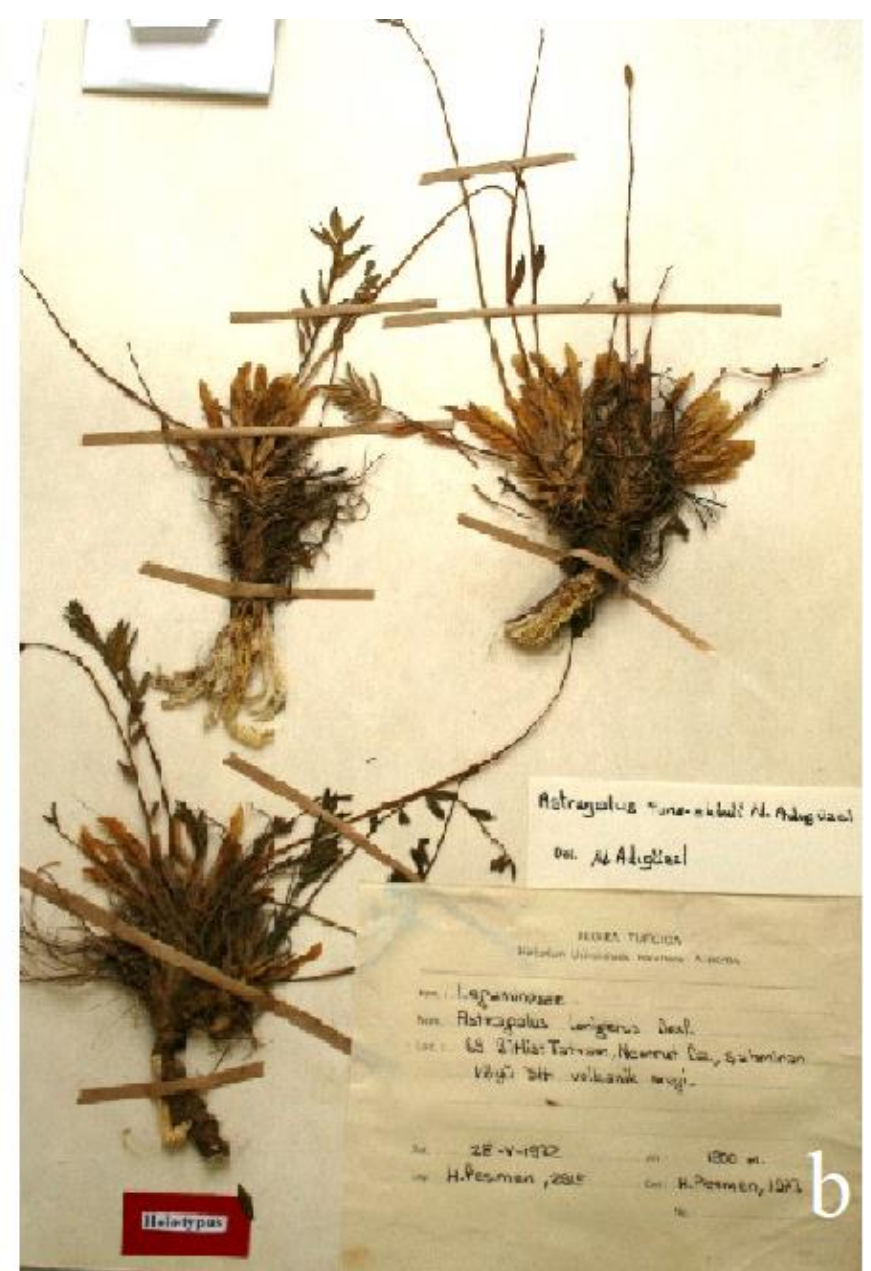

Figure 2. a. Lectotype specimen of Astragalus chamaephaca (B, URL 1), b. Holotype specimen of A. tuna-ekimii (GAZI).

Table 2. Comparison of Astragalus chamaephaca and A. tuna-ekimii

\begin{tabular}{|c|c|c|}
\hline Characteristics & A. chamaephaca & A. tuna-ekimii \\
\hline Stipules & $10-20 \mathrm{~mm}$, membranous, adnate to petiole & $10-20 \mathrm{~mm}$, membranous, adnate to petiole \\
\hline Leaves & $5-12 \mathrm{~cm}$, erect to prostrate, sparsely white hairs, otherwise glabrous & $10-16 \mathrm{~cm}$, sparsely white hairs \\
\hline Leaflets & $\begin{array}{l}\text { (7-) 9-11 pairs, } 7-15 \times 2-6 \mathrm{~mm} \text {, narrowly elliptic to elliptic, subacute to } \\
\text { narrowly rounded, glabrous }\end{array}$ & $\begin{array}{l}\text { 13-15 pairs, } 6-16 \times 3-4 \mathrm{~mm} \text {, narrowly elliptic to lanceolate, } \\
\text { glabrous }\end{array}$ \\
\hline Peduncle & absent to $0.5 \mathrm{~mm}$, glabrous or loosely covered with subappressed hairs & $\begin{array}{l}\text { up to } 4 \mathrm{~mm} \text {, glabrous or loosely covered with subappressed } \\
\text { hairs }\end{array}$ \\
\hline Raceme & 2-3 flowered & 2-3 flowered \\
\hline Bracts & $\begin{array}{l}\text { 4-10 mm, narrowly ovate to nearly orbicular, glabrous or very shortly } \\
\text { ciliate it upper part }\end{array}$ & $\begin{array}{l}7-8(-10) \mathrm{mm} \text {, narrowly ovate-lanceolate, glabrous or very } \\
\text { shortly ciliate it upper part }\end{array}$ \\
\hline Pedicels & $0.5-1 \mathrm{~mm}$ glabrous to sparsely hairy & up to $3.5 \mathrm{~mm}$ \\
\hline Calyx & 13-20 mm, tubular, glabrous & 13-16 mm, tubular, sparsely hairy \\
\hline Calyx teeth & 4-7 $\mathrm{mm}$, sparsely to rather densely hairy & 4-6 mm, sparsely to loosely white hairy \\
\hline Standard & $32-42 \mathrm{~mm}$, yellow to pinkish & ca. $35 \mathrm{~cm}$, yellow \\
\hline Ovary & sessile, glabrous to hairy & sessile, hairy \\
\hline
\end{tabular}

3.3. Astragalus scabrifolius Boiss., Diagn. Pl. Orient. ser. 1, 2: 81 (1843) (sect. Incani DC.).

Syn.: Astragalus darendensis Podlech \& Ekici, Feddes Repert. 119(1-2): 26 (2008), syn. nova.

Astragalus specimens were collected by Nydegger (Nydegger 42631, MSB004034, Fig. 3b) and described as a new species, A. darendensis, by Podlech \& Ekici in 2008. However, the earlier samples collected from the same area by Aucher 1339 (P00623281, Fig. 3a) were described as a new species, $A$. scabrifolius, by Boissier in 1843 . While examining the material of $A$. darendensis and type materials of $A$. scabrifolius, it was observed that $A$. darendensis is described from an insufficient sample. The 
grazing sample also seems to be insufficient. The peduncle in the original article is called "2-5 cm straight or curved", but these features do not appear to be of the type (Fig. 3b). It looks like grazing. The samples have the

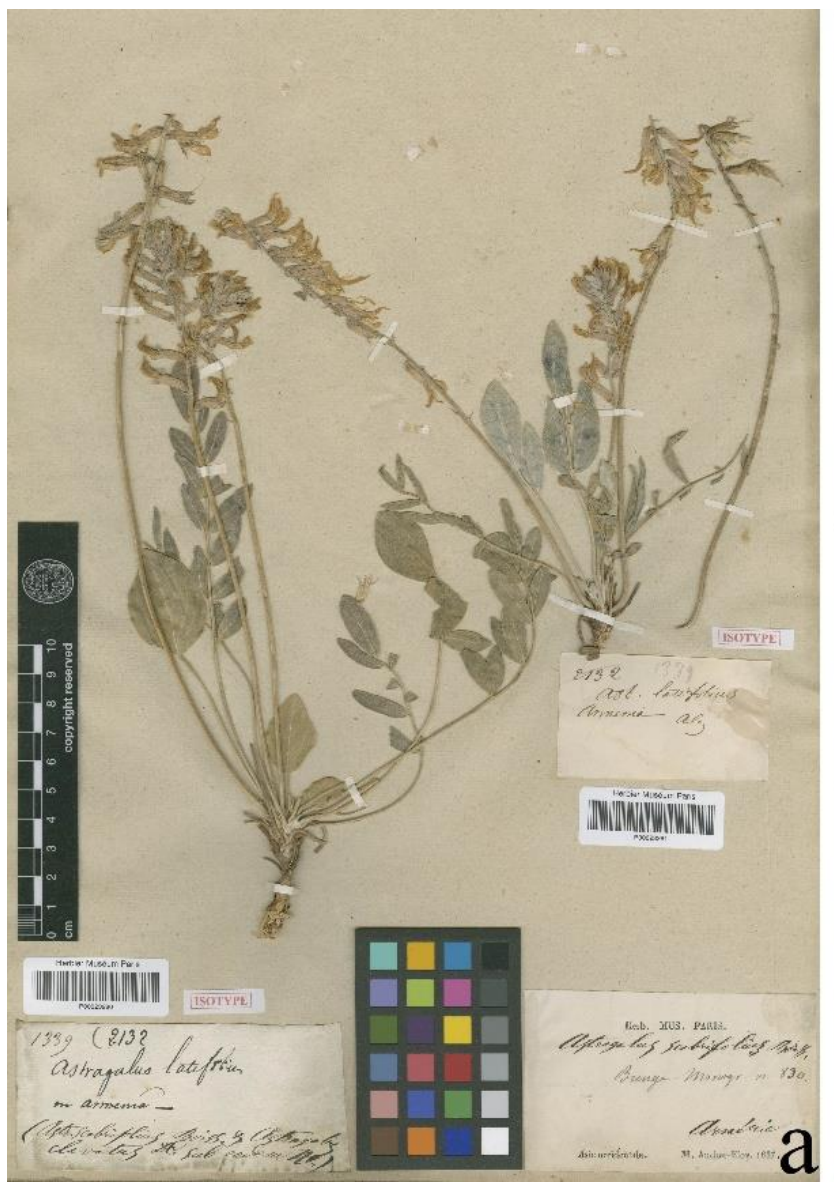

same properties as $A$. scabrifolius. For these reasons, $A$. darendensis is reduced to the synonym of $A$. scabrifolius.

The comparison of Astragalus darendensis and A. scabrifolius is given in Table 3.
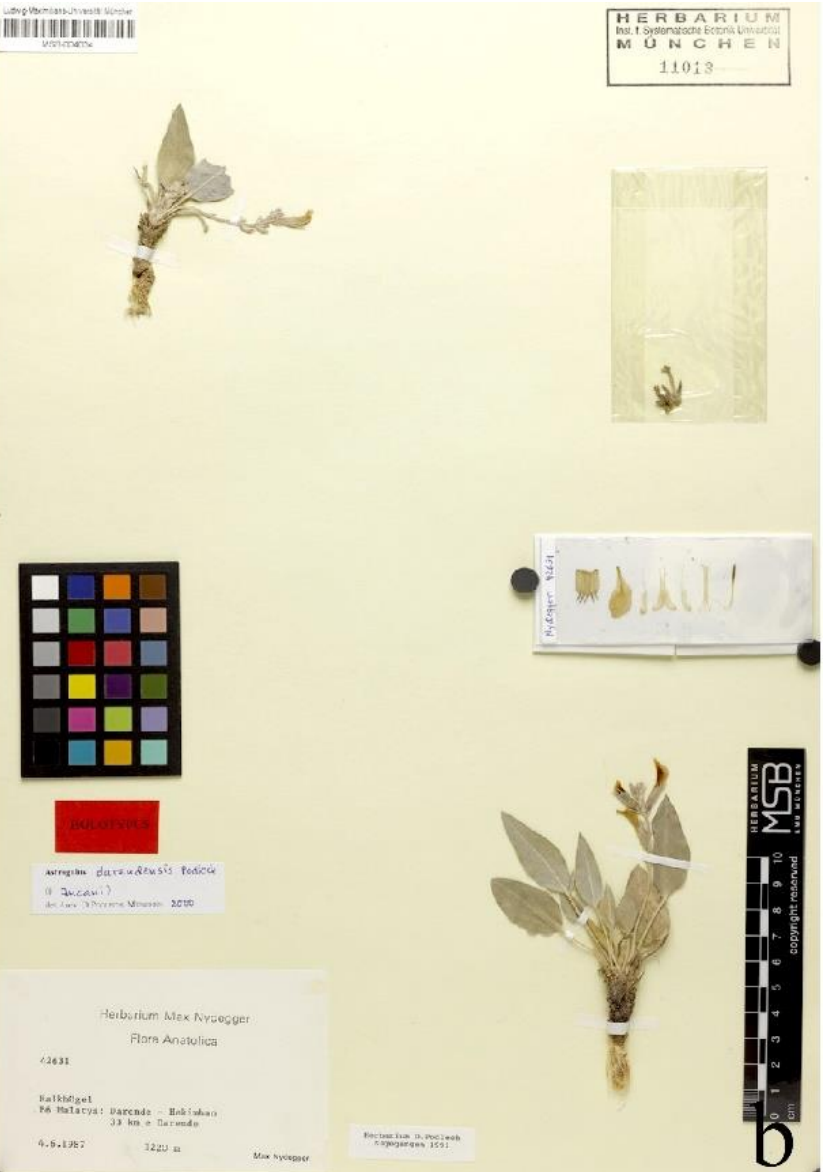

Figure 3. a. Type specimen of Astragalus scabrifolius (P, URL 2) and b. A. darendensis (MSB, URL 3)

Table 3. Comparison of Astragalus scabrifolius and A. darendensis

\begin{tabular}{|c|c|c|}
\hline Characteristics & A. scabrifolius & A. darendensis \\
\hline Stipules & narrowly triangular, $6-7 \mathrm{~mm}$ & narrowly triangular, $8-12 \mathrm{~mm}$ \\
\hline Leaves & $8-14 \mathrm{~cm}$ & $3-8 \mathrm{~cm}$ \\
\hline Leaflets & $\begin{array}{l}1-2 \text { pairs, } 2-15(-30) \times 2.5-6(-8) \mathrm{mm} \text {, narrowly ovate to narrowly elliptic, primary leaves } \\
\text { reduced to the terminal leaflets in lower part, } 4-6(-8) \text { pairs in upper part }\end{array}$ & $\begin{array}{l}\text { one leaflets, } 30-40 \times 9-17 \mathrm{~mm} \text {, narrowly } \\
\text { ovate-triangular in lower part }\end{array}$ \\
\hline Peduncle & $5-16 \mathrm{~cm}$, appressed, white hairy & $2-6 \mathrm{~cm}$, densely hairy \\
\hline Raceme & 5 - to many flowered & up to 10 flowered \\
\hline Bracts & whitish, narrowly triangular, $2-3 \mathrm{~mm}$, hairy & $\begin{array}{l}\text { whitish, narrowly triangular, } 4-5 \mathrm{~mm} \text {, } \\
\text { hairy }\end{array}$ \\
\hline Calyx & $8-12 \mathrm{~mm}$ tubular, obliquely gibbous at base, white to white-black hairy & $\begin{array}{l}12-14 \mathrm{~mm} \text {, tubular, obliquely gibbous at } \\
\text { base, densely hairy }\end{array}$ \\
\hline Calyx teeth & 2-4 mm, subulate & 3-4 mm, subulate \\
\hline Standard & $15-18 \mathrm{~mm}$, oblong elliptic & ca. $20 \mathrm{~cm}$, oblong-obovate \\
\hline Ovary & with a stipe, ca. $1 \mathrm{~mm}$, hairy & sessile, hairy \\
\hline Legume & nearly sessile (unripe), pendulous, narrowly elliptic, acuminate, with hairy & unknown \\
\hline
\end{tabular}

Acknowledgements: We would like to thank Dr. Hans-Joachim Esser (Curator and Research Scientist, Botanische Staatssammlung München).

\section{References}

Adıgüzel, N. (1999). A new species of Astragalus (Fabaceae) from East Anatolia, Turkey. Annales Botanici Fennici, 36, 231-233.

Boissier, E. (1843). Diagnoses Plantarum Orientalium Novarum. Genevae, Switzerland, Typographia Ferd. Romboz press., 1(2), 81 pp.

Chamberlain, D.F., \& Matthews, V.A. (1970). Astragalus. In: P.H. Davis, (Ed.). Flora of Turkey and the East Aegean Islands, 3, pp. 49-254. Edinburgh University Press, Edinburgh.
Chaudhary, L.B., Rana, T.S., \& Anand, K.K. (2008). Current status of the systematics of Astragalus L. (Fabaceae) with special reference to the Himalayan species in India. Taiwania, 53(4), 338-355. http:// dx.doi.org/ 10.6165/tai.2008.53(4).338

Dural, H., Tugay, O., Ertuğrul, K., Uysal, T., \& Demirelma, H. (2007) Astragalus turkmenensis (Fabaceae), a new species from Turkey. Annales Botanici Fennici, 44, 399-402.

Ekim, T., Aytaç, Z., \& Duman, H. (1991). Some new taxa of Astragalus L. and comments on Turkish Caragana Lam. Tzaiszia, Kosice, 1, 17-29.

Freyn, J. (1890). Plantae novae Orientales. eit Oesterreichische Botanische Zeitschrift, 40 (11), 402.

Podlech, D. (1999). New Astragali and Oxytropis from North Africa and Asia, including some new combinations and remarks on some species. Sendtnera, 6, 135-174. 
Podlech, D., \& Ekici, M. (2008). Some new and interesting Astragalus species (Fabaceae) from Turkey. Feddes Repertorium, 119(1-2), 2436. http://dx.doi.org/1.1002/fedr.200711147

Podlech, D., \& Zarre, S. (with collaboration of Ekici, M., Maassoumi, A.A., Sytin, A. (2013). A taxonomic revision of the genus Astragalus L. (Leguminosae) in the Old World 1-3. Wien, Naturhistorisches Museum Press, $2117 \mathrm{pp}$.

Thiers, B. (2020). Index Herbariorum: A global directory of public herbaria and associated staff. New York Botanical Garden's Virtual Herbarium. Retrieved from http://sweetgum.nybg.org/ih/

Turland, N.J., Wiersema, J.H., Barrie, F.R., Greuter, W., Hawksworth, D. L., Herendeen, P.S., Knapp, S., Kusber, W.-H., Li, D.-Z., Marhold, K., May, T.W., McNeill, J., Monro, A.M., Prado, J., Price, M.J. \& Smith, G. F. (eds.) (2018). International Code of Nomenclature for algae, fungi, and plants (Shenzhen Code) adopted by the Nineteenth International Botanical Congress Shenzhen, China, July 2017. Regnum Vegetabile 159. Glashütten: Koeltz Botanical Books. https://doi.org/10.12705/ Code. 2018

URL.1. https://plants.jstor.org/stable/viewer/10.5555/al.ap.specimen. b_10_0186955

URL.2. http://coldb.mnhn.fr/catalognumber/mnhn/p/p00623281

URL.3.http://psimg.jstor.org/fsi/img/size1/alukaplant/msb/phase_01/ msb0004/msb004034.jpg

URL.4.https://basbg.unibas.ch/modules/mod_basbg_dataentry/showim age.php?id=https://basbg.unibas.ch/BASBGherbarium/zoom/000/B ASBG-00000031

Zarre, S., \& Azani, N. (2013). Perspectives in taxonomy and phylogeny of the genus Astragalus (Fabaceae): a review. Progress in Biological Sciences, 3, 16. http://dx.doi.org/10.22059/PBS.2013.32086 